\author{
ÁsDís Rósa MAGNúSDÓTTIR \\ HÁSKÓLA ÍsLANDS
}

\title{
Um Matéo Maximoff
}

Matéo Maximoff er einn pekktasti höfundur Rómafólks af sinni kynslód. ${ }^{1}$ Hann fæddist á Spáni árið 1917 en fór með fjölskyldu sinni til Belgíu og sî̉an til Frakklands par sem hann settist að í nágrenni Parísar. Fjórtán ára gamall varð hann munaðarlaus og purfti að sjá fyrir systkinum sínum, m.a. með pví að gera við og pvo potta og pönnur. Hann var í fangabúðum fyrir flökkufólk í Frakklandi um nær priggja ára skeið og barðist lengi fyrir opinberri viðurkenningu á pjóðarmorði á Rómafólki í sîđari heimsstyrjöld. Fyrstu skáldsögu sína skrifaði hann í fangelsi en hún kom út árið 1946. Maximoff rak kaffihús og vann með ýmsum pekktum ljósmyndurum og kvikmyndagerðarmönnum um árabil. Hann ferðaðist og tók mikið af ljósmyndum af Rómafólki víða um lönd og gaf pær út í bókinni Les Gens du voyage (Flökkufólk) árið 1995.

Matéo Maximoff gekk aldrei í skóla og lærði sjálfur að lesa og skrifa. Hann samdi ljóð, skráði fjölmargar munnmælasögur og byggði flest ef ekki öll skáldverk sín á menningu Rómafólks. Hann var alla tío ötull baráttumaður fyrir réttindum Rómafólks og viðurkenningu á tungumáli peirra og menningu. Flest verk sín gaf hann út sjálfur, samtals átta skáldsögur og eitt smásagnahefti. Í sumum skáldverka sinna sækir hann innblástur í eigið líf en segir einnig frá ævi sinni og fjölskyldu sinnar í tveimur bókum: Ce monde qui n'est pas le mien (Dessi heimur sem ég pekki ekki, 1992) og Routes sans roulottes (Vegir án vagna, 1993). Maximoff samdi nánast öll skáldverk sín á frönsku. Hann lést árið 1999.

1 Nánar er sagt frá ævi og ritverkum Matéos Maximoff í greininni „Sjálfsmynd, framandleiki og tungumál í verkum Matéos Maximoff: rómíska í íslenskum býdingum“ sem finna má í pessu hefti Milli mála, bls. 111-133. 
Sagan sem hér birtist í íslenskri býðingu kom út árið 1986 í smásagnasafninu La poupée de Mameliga. Le livre de la peur (Brúða Mameligu. Bók óttans). Par er að finna hrollvekjandi sögur um drauga og afturgöngur af ýmsu tagi sem gjarnan voru sagðar pegar vakað var yfir líkum. 